UDC 378.1

DOI: https://doi.org/10.17721/2415-3699.2021.14.08

Yevhenii Spitsyn, PhD (Pedagogy), Prof. ORCID iD: 0000-0001-8385-4789

Victoria Leshchenko, Master Stud.

Taras Shevchenko National University of Kyiv, Kyiv, Ukraine

\title{
BOLOGNA PROCESS IN UKRAINE: TRENDS, PROBLEMS AND PERSPECTIVES
}

\begin{abstract}
The study analyzed the process of transformation of the higher education system in Ukraine within the framework of the Bologna process principles implementation; the current state, problems and degree of key provisions implementation under the Bologna Declaration are characterized; the tendencies of development of the Bologna process in Ukraine are pointed out; possible ways to increase the efficiency of the higher education system of Ukraine have been identified.
\end{abstract}

Keywords: The Bologna process, credit transfer system, mobility, development trends, monitoring of education quality.

Introduction. An integral part of Ukraine's sustainable development in the long term has been the development of a high-quality and comprehensive education sector. The challenges for our country were fisible with no exceptions at every stage of implementing the state strategy for the education development, but the very initial step was a reasonable and justified by European practice decision to implement the Bologna Process. Reform, as world experience shows, is a dynamic and complex phenomenon that requires consistent decisions at both the regulatory and executive levels. Therefore, it is not surprising that Ukraine did not become an exception and rather quickly outlined the peculiarities of the Bologna process implementation in higher education institutions (hereinafter - HEI). Not only the difference between the actual results and the planned ones was noticeable, but also the fact that the newly created education system appeared as an autonomous consequence of the implemented reforms, but not as a primary goal, which thus remains unreached in many parameters. This has led to the need to revise and rethink the process of reform tasks realization.

The purpose of the article is to highlight trends in the Bologna process in Ukraine. Corresponding tasks were:

1) Analyze the current state of Bologna process principles implementation over the past decade in Ukraine.

2) Describe the current state, problems and implementation degree of key provisions within the Bologna Declaration.

3) Identify trends in the Bologna process in Ukraine.

Analysis of recent research and publications. The issues of determining the state of the Bologna process in Ukraine were studied in their works by such Ukrainian scientists as I. Bekeshkina, O. Zlobina, and A. Koretska [Bekeshkina, Zlobina, 2012]. The process of introduction of key principles of the Bologna process in Ukraine was analyzed by V. Kremin [Kremen, 2008] and T. Kozma, M. Rebay, A. Shkhida [Kozma, Rébay, Óhidy, Szolár, 2014]. Based on the results of these studies, there is a need to identify current trends in the Bologna Process in Ukraine to improve the results of the implemented reforms.

Presentation of the main positions.. To clarify the status and highlight the results of the Bologna Process in Ukraine, in October-November 2020 we conducted a study that included interviews with participants in the educational process and surveys of 410 students representing different types of universities, in particular:

- multidisciplinary (45.37\%): Taras Shevchenko National University of Kyiv (Kyiv), National University KyivMohyla Academy (Kyiv), V.N. Karazin Kharkiv National University (Kharkiv), Ivan Franko National University of Lviv (Lviv), Taras Shevchenko National University, "Chernihiv Collegium" (Chernihiv);
- specialized (54.63\%): Kharkiv National Pedagogical University named after G.S. Skovoroda (Kharkiv), Municipal Institution "Kharkiv Humanitarian and Pedagogical Academy" of Kharkiv Regional Council (Kharkiv), Kyiv National University of Trade and Economics (Kyiv), Kharkiv State Zooveterinary Academy (Kharkiv), Kharkiv Regional Institute of Public Administration of the National Academy of Public Administration under the President of Ukraine (Kharkiv), Kharkiv National Economic University named after Semyon Kuznets (Kharkiv), National Aerospace University named after . ME Zhukovsky "Kharkiv Aviation Institute" (Kharkiv), Donetsk Law Institute of the Ministry of Internal Affairs of Ukraine (Donetsk), South Ukrainian National Pedagogical University named after K.D. Ushinsky (Odessa).

To conduct the survey, we developed a system of questions that allowed students to demonstrate a degree of awareness about the Bologna Process principles and an understanding of their capabilities in accordance with this process; to find out whether the key provisions of the Bologna Declaration really function in $\mathrm{HEI}$ in the form in which they are declared by the regulatory framework of Ukraine; determine the state of the infrastructure of $\mathrm{HEI}$ and its compliance with the needs of the educational process; find out how students evaluate the implementation of the Bologna Process and what ways to improve they can point out. The majority of all respondents - $66.34 \%(75 \%$ of respondents studying in sectoral $\mathrm{HEI}$ and $54.3 \%$ of respondents studying in multi-sectoral higher education institutions believe that the implementation of the principles of the Bologna Process is mostly "on paper" and is not implemented during educational process. The majority of all respondents $(70 \%)$ attribute this to the lack of motivation and unwillingness of teachers to change.

The first block of the questionnaire contained questions related to the credit-module organization of education process in $\mathrm{HEI}$. To the question "What scale is used for your knowledge and skills assessment in the HEI?" $68.3 \%$ of respondents answered that the evaluation is based on the 100-points scale, $21.7 \%$ of respondents - on a four-point scale, $10 \%$ of respondents said that the evaluation is based on both scales. The answers of the respondents according to the types of higher education institutions are given below in Fig. 1 and 2. Such answers may indicate that a significant percentage of teachers assess students' knowledge and skills on a four-point scale, that is, grades are announced with reference to this scale, and documentation is completed referring to a 100-points scale. Thus, there is a "dual system" of assessment of students. This trend is most often observed in sectoral higher education institutions. Students studying in the $\mathrm{HEl}$, where the so-called "dual assessment system" operates, often express a negative attitude to the assessment system in the institution as a whole, noting that 
the score on the credit-module system is inaccurate and incomprehensible to them. This leads to the answers to the question "Which of the following do you think are features of the Bologna Process?", and $40 \%$ of respondents did not identify a unified assessment system based on ECTS provisions as a sign of the Bologna Process.

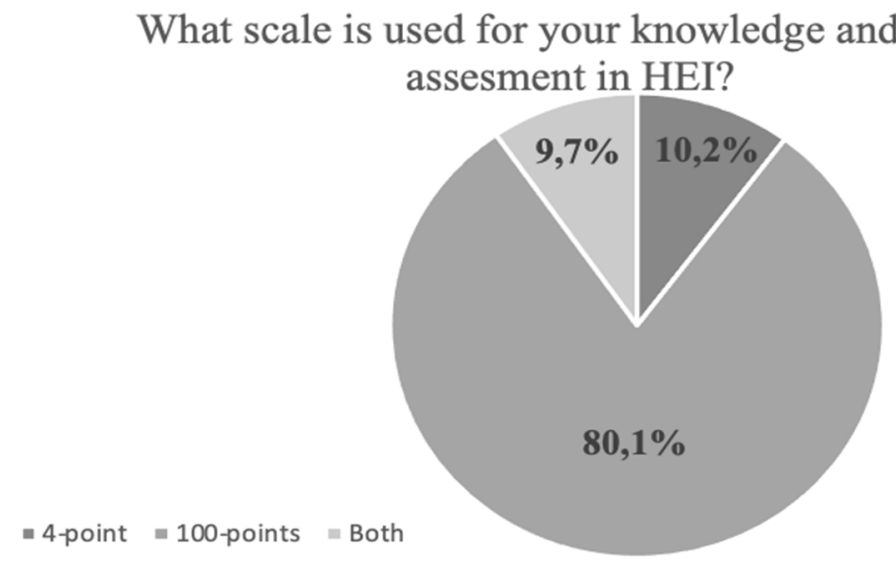

Fig. 1. Student responses from multidisciplinary higher education institutions

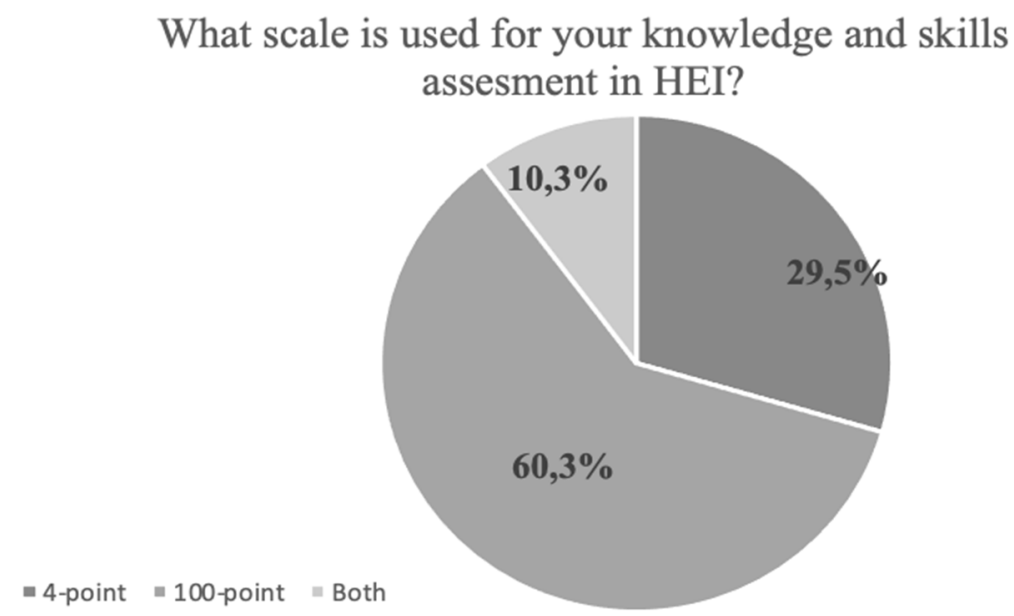

Fig. 2. Student responses from specialized higher education institutions

The majority of students $(70 \%)$ do not understand the essence of the concept of "credit" and point that all students in their group receive credit "automatically". At the same time, $80 \%$ of respondents say that the assessment of their answer during the exam depends entirely on their activity and attendance during the semester. For example, if the maximum score was obtained during the semester, it guarantees the highest score on the exam and vice versa, the minimum score does not allow you to get the highest score for the exam. Accordingly, such results may indicate that these forms of final control do not perform their function, and the evaluation process itself contains remnants of the Soviet approach.

The vast majority of students $(70 \%)$ do not understand the process of free choice of disciplines, and more than half of respondents $(62.2 \%)$ say that they do not choose any discipline. Moreover, this trend is more observed among master's students. This may be a confirmation of the existence of normative "gaps", because to open a subgroup to study the discipline requires a minimum set number of students, and the number of master's groups, compared to bachelor's, is usually lower, so students' free choice is somewhat limited.

Respondents' answers about the objectivity of assessment in $\mathrm{HEl}$ were unexpected: only $20 \%$ of respondents believe that assessment in their institution is objective, $35.1 \%$ of respondents - mostly objective, $44.9 \%$ of respondents say that assessment in institution occurs mostly not objectively. The answers of the respondents according to the types of higher education institutions are given below in Fig. 3 and 4 . This shows that more than half of the respondents $(52.2 \%)$ studying in multidisciplinary institutions and the vast majority of respondents (73.2\%) studying in specialized institutions believe that the assessment is not objective.

To find out the reasons for this opinion among students, we conducted an additional anonymous survey in those $\mathrm{HEls}$, where the percentage of people who reported the bias of assessment in their HEls was the highest. The survey included the question "Which of the following is the reason for biased assessment in the HEI?": $40.5 \%$ of respondents said that they are not familiar with the evaluation criteria of most teachers, $60.5 \%$ of respondents believe that the evaluation process in the $\mathrm{HEl}$ contains a corruption component, $30.1 \%$ of respondents - teachers do not meet their own assessment criteria, changing them in the learning process, $14.4 \%$ of respondents - it is difficult to identify such reasons (the total percentage exceeds 100 , because in this issue you could choose several answers). Such results may indicate that a large percentage of teachers do not acquaint students with their own assessment criteria at all, some teachers acquaint with the assessment criteria, but do not follow them in the learning process; Unfortunately, the vast majority of respondents $(60.5 \%)$ believe that there is a corruption component in their institutions, and this phenomenon is more common in specialized institutions. 


\section{Would you consider assesment of your knowledge and skills by your institution as objective?}

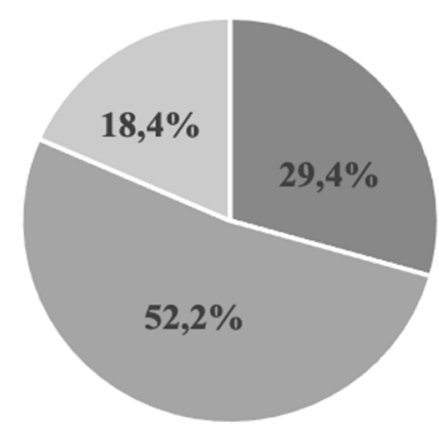

- Yes, objective = Mostly objective $\quad$ Mostly biased

Fig. 3. Answers of respondents in multidisciplinary higher education institutions

\section{Would you consider assesment of your knowledge and skills by your institution as objective?}

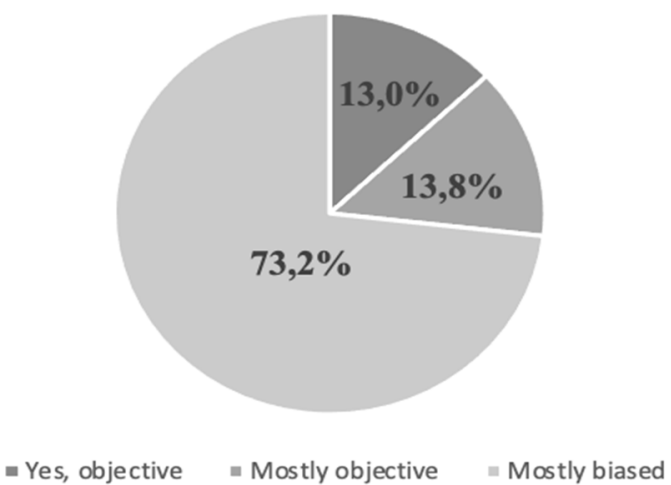

Fig. 4. Answers of respondents in specialized higher education institutions

The survey also shows low awareness of students about the basic provisions of ECTS: only $30 \%$ of respondents correctly indicate the number of hours corresponding to 1 ECTS credit, explaining this by the fact that this information is unnecessary for them. This indicates a low understanding by students of the possibilities of the Bologna Process for them. The above problem is closely related to student mobility: only $35.1 \%$ of respondents are generally aware of this possibility. When asked: "Did you participate in the mobility program", only $6.9 \%$ of respondents said that they were participants in mobility programs.

Determining the difference between a bachelor's and a master's degree was problematic for students. The majority of students $(65.1 \%)$ could not distinguish between the two levels (73\% of undergraduate students: $25 \%$ of first-year students, $10 \%$ of second-year students, $34 \%$ of third-year students, $31 \%$ of fourth-year students, and $60 \%$ of students). master's level: $44 \%$ of first-year students, $56 \%$ second-year students.

To the question "How many hours a week do you spend on independent tasks?" the majority of respondents (60\%) answered that they spend more than 16 hours a week performing independent tasks; $20 \%$ is given from 5 to 10 hours / week; $10 \%$ - up to 5 hours / week; $10 \%$ - this indicates a high overload of students.

To the question "How is the modular control of your knowledge and skills is conducted in HEl?" $90.5 \%$ stated that the modular control takes the form of testing, $63.9 \%$ - in the form of an oral interview, $59.5 \%$ - in the project form, $2 \%-$ in the format of a colloquium (the total percentage exceeds 100 , because respondents could choose several options).

The quality of the organization of the educational process, the possibility of diversification of the learning process is provided, first of all, by the level of infrastructure in the institution, so the second block of questions deals with determining the state of the institution and its compliance with the educational process. In general, students assess the state of infrastructure in their institution as satisfactory. At least, answering the question about the presence of the components necessary for the successful organization of the educational process in $\mathrm{HEI}$, the vast majority of students confirmed that the conditions generally exist (Fig. 5).

However, the availability of the necessary infrastructure does not guarantee its use in the educational process. In particular, despite the fact that $68 \%$ of students confirmed that their free economic zone has a modern library, only $30 \%$ of respondents said that they found the necessary and relevant information there. The situation is similar with the presence of computer classes. Although they are present in $93.9 \%$ of freelancers, only $58 \%$ of students are satisfied with the opportunities to use computers in extracurricular time to perform independent work. The rest are either dissatisfied with the technical condition of the PC, which makes it impossible to use it effectively, or do not have such an opportunity at all $(9 \%)$. The situation with the possibility to have free access to the Internet on the territory of the institution is similar. $30 \%$ of respondents are satisfied with it, $20 \%$ are dissatisfied, unfortunately, half of the students do not have such an opportunity at all. 


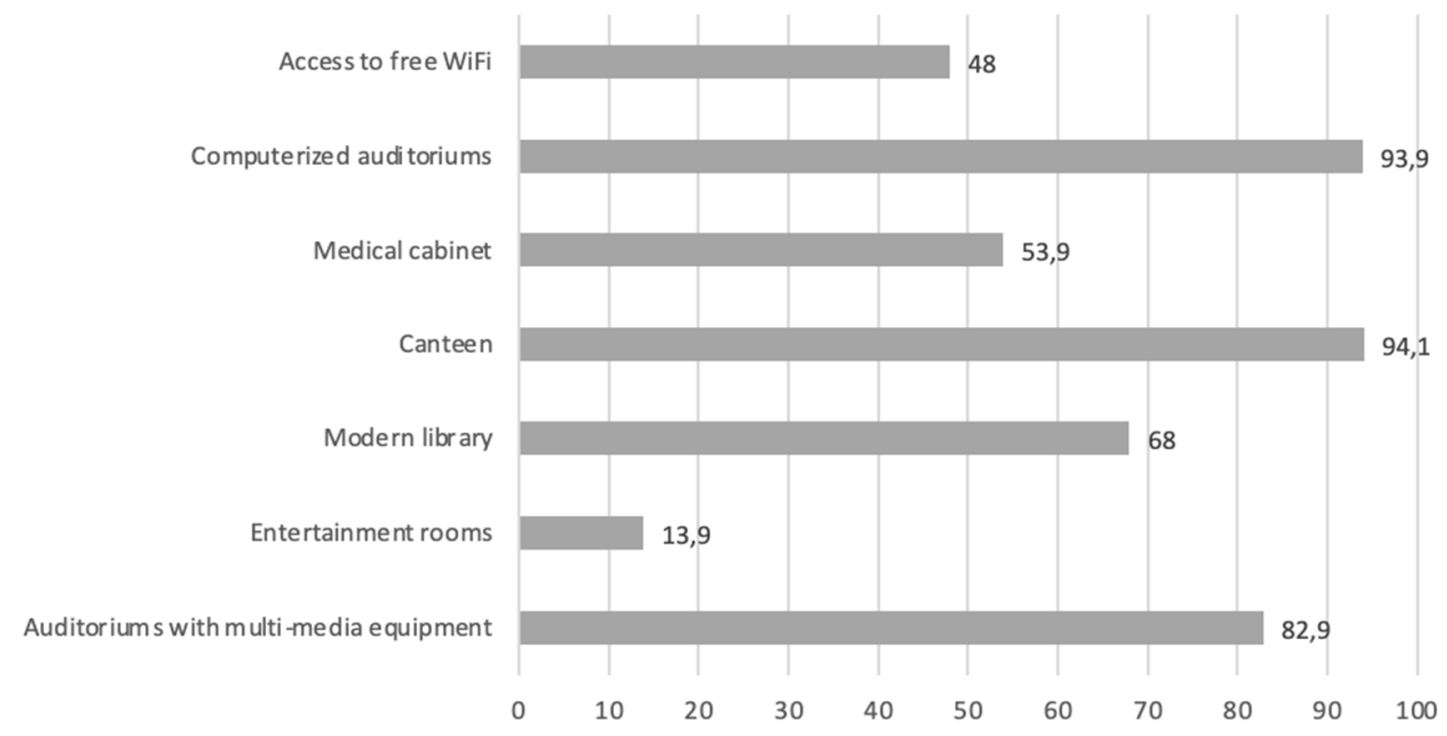

Fig. 5. What is items from the list are present in your HEl?

As for the prospects of solving these problems, the majority of students $(70 \%)$ believe that it is necessary to work on motivating teachers and increase awareness of participants in the educational process with the possibilities of the Bologna process through training, while most teachers $(65.04 \%)$ believe, that it is necessary to create clear criteria by which they could determine the compliance of the educational process with the principles of the Bologna Process.

Based on the results of the study and analysis of scientific sources, we can distinguish between positive and negative trends in the Bologna process. A positive trend is the significant development of legislation in the field of higher education. The gradual creation of a balanced regulatory system in the education sector may not be fast enough and comprehensive, but it is a dynamic phenomenon. In addition to creating a regulatory framework, the regulatory framework must also meet the challenges of both external and internal influence. For example, the COVID-19 pandemic crisis has confirmed that the adaptation of educational institutions to the new realities of the educational process requires an orderly and clear administrative mechanism, which in turn will contain technical and specialized recommendations for overcoming the crisis. Such non-standard challenges still require standardized and unified approaches that will leave discretion for the autonomy of each individual institution, but within clear and effective rules and recommendations. In Ukraine, the practice of applying international experience and awareness of the need for an effective response to changing educational needs is noticeable, which creates a fruitful basis for the development of a high-quality regulatory framework.

The result of the efforts and professional realization of students both in Ukraine and in most countries of the world is to obtain a diploma of higher education. However, it is important to discuss the "weight" of the diploma and its further impact, for example, on career opportunities and development. The main emphasis is on the comparison and standardization of knowledge between students of different higher education institutions in different countries. The universal solution was the unification of diplomas between the countries participating in the Bologna Process, bringing the recognition criteria to those that can be objectively compared. In practice, this process is much more complex and has a multi-component structure. Despite the fact that Ukrainian diplomas still need an additional recognition procedure in Europe, the unification process facilitates the "leakage" of Ukrainian specialists outside Ukraine. At the same time, the reverse process is taking place within
Ukraine - higher education institutions have received partial autonomy for the issuance of diplomas, which, in turn, provided an opportunity to rate the diplomas received.

Today's global challenges are sudden and continuously suppressive. In both the first and the second case, the ideal response to such challenges would be rapid and comprehensive adaptability. However, the pervasiveness of crisis phenomena is by its nature integral, which cannot be said about the necessary interaction of the administrative and executive components of the educational process. Decisions and recommendations are traditionally difficult and slow in Ukrainian practice with the hierarchy of approvals and responsibilities at both the legislative and executive levels. The same model of interaction is followed by each individual agent of the education sector from schools to universities, thus slowing down the pace of change at each stage of decision-making.

High competence of people with a diploma of higher education, at first glance, is certainly a positive phenomenon. However, the presence of a large number of fictitious institutions, a high level of corruption in the process of acquiring knowledge and their assessment indicates a significant oversaturation of the industry with low-quality consumers and providers of educational services. In turn, this leads to expected but destructive manifestations, such as low quality of education, irrational use of intellectual capital and a large number of people who do not work in education sector.

The term "corruption" is increasingly appearing in the Ukrainian information space with stable dynamics and spread. The processes of creating government institutions with further struggle against the judiciary, international support and demand for reforms, exhausted public attitude to corruption at every stage of the state and social system all this, however, only indicates the ingrained type of corruption in Ukrainian society. Building high-quality bases for change is impossible without a holistic and transparent mechanism for such development. Corruption makes significant and sometimes irreversible adjustments to such processes and requires a careful, consistent and comprehensive approach to overcoming them.

The volume and expenditure of financial support for higher education institutions is as historically problematic as corruption in Ukraine. The budgetary and contractual form of financial resources for universities is outdated and too simplistic, as it has systemic risks at its core. If the state does not have enough opportunities to finance one or another 
educational institution, in the long run such an institution will be prone to the need to seek alternative sources of funding in order to maintain its teaching staff and structure in general. If this funding is made possible through donor, interuniversity, grant or fund initiatives, the sustainability of the institution will have fewer systemic risks than in case such funding comes from non-transparent, non-targeted and corrupt activities. It is worth noting that Ukrainian universities are aware of this path and are beginning to actively participate in programs of interaction with the corporate and private sectors in order to build synergies and new opportunities. In this way, it may be important to stimulate such interaction between government agencies through effective administrative and regulatory support.

Adjacent is the tendency of a person to go through the stages of education and its application in a scientific or industrial environment. Approaches to the interpretation of the function of the university, both capitalist and socialist models of development, contain an understanding of the need to apply the acquired knowledge for industrial and social benefit. In our opinion, more historically justified guidelines in this context are the models of functioning of Western types of higher education institutions with a significant history of success in creating both research discoveries and the production of highly qualified specialists for various sectors of the economic and social spheres. Ukraine is characterized in this direction by the lack of a stable and confident understanding of the possibilities of university autonomy in cooperation with other stakeholders, and the tendency of passive direction of the authorities, state navigation of their activities.

Conclusions. For almost two decades, Ukraine has been an active participant in the creation of the European Higher Education Area, which has resulted in many changes in the national higher education system, including:

- the structure of degrees is transformed;

- the mobility process has been introduced;

- diplomas and appendices to them are unified;

- the system of training organization was changed (to credit-module);

- mechanisms for ensuring the quality of higher education have been developed;

- measures were initiated to increase the level of employment of students.

The implementation of the principles of the Bologna Process in Ukrainian higher education institutions is contradictory: the legislative base is rapidly developed, which expands the opportunities of participants in the educational process, but at the same time students and teachers do not understand them enough; assessment in institutions is based on a credit-module system, but this process is often formal in nature, as the vast majority of students note the functioning of the "dual system" of assessment, respectively, the vast majority of students do not understand its essence; introduced the possibility of "free trajectory of the student", but the ability to independently choose a certain part of the subjects from the proposed list has a smaller percentage of students; anticorruption departments and divisions have been set up, but most students report a corruption increase; a mobility mechanism has been created, but for various reasons, despite their desire, participants in the educational process often do not use this opportunity, and the mobility process itself has proved to be passive.

Based on the obtained data on the state of Bologna process implementation in the system of higher education in Ukraine, and comparing them with the data of 2012, we identified a number of trends in the Bologna process implementation in Ukraine, including:

1. Stable development of legislation in the field of higher education.

2. Rapid growth in demand for the teaching profession.

3. Slow and partial implementation of the necessary measures in the educational space of the HEI;

4. The growing level of corruption in education.

5. Increasing level of dissatisfaction and distrust in the free evaluation system.

6 . Stable passivity of the mobility programs for students.

7. Decreased trust in national institutions for quality assurance in higher education.

References

Iryna Bekeshkina, Olena Zlobina: Bologna process in Ukraine: that worked and that failed. Kyiv, 2012. 3-11.

Vasyl Kremen. (ed) (2008). Basic principles of development of higher education in Ukraine in the context of the Bologna process. Kyiv, 2008

Tamás Kozma, Magdolna Rébay, Andrea Óhidy, Éva Szolár (ed.): The Bologna Process in Central and Eastern Europe. Wiesbaden, Springer VS, 2014.322-354

Walker, B., \& Salt, D. (2012). Resilience thinking: sustaining ecosystems and people in a changing world. Washington, DC: Island Press.

The first report on trends in higher education in Europe. URL: https://eua.eu/resources/publications/677:trends-in-learning-structures-inhigher-education.html (access date: 02.01.2021)

Sorbonne Joint Declaration. Joint declaration on harmonisation of the architecture of the European higher education system. URL:http://www.ehea.info/media.ehea.info/file/1998_Sorbonne/61/2/1998_S orbonne_Declaration_English_552612.pdf_(access date: 06.12.2020)

Communiqué of the Conference of European Ministers Responsible for Higher Education, Bergen. URL: http://www.ehea.info/media.ehea.info/file/2005_Bergen/52/0/2005_Bergen_Communique_english_580520.pdf_(access date: 12.01.2021)

Law of Ukraine "On Higher Education" as amended on 25.09.2020. URL https://zakon.rada.gov.ua/laws/show/1556-18\#Text (access date: 12.01.2021) Надійшла до редколегії 23.04.21

Євгеній Спіцин, канд. пед. наук, проф.

ORCID iD: 0000-0001-8385-4789,

Вікторія Лещенко, магістр

Київський національний університет імені Тараса Шевченка, Київ, Україна

\section{БОЛОНСЬКИЙ ПРОЦЕС В УКРАЇНІ: ТРЕНДИ, ПРОБЛЕМИ ТА ПЕРСПЕКТИВИ}

Досліджено тривалий процес трансформації системи вищої освіти України під впливом впровадження принципів Болонської конвенції, що характеризується динамічністю і періодично супроводжується виникненням розбіжностей між запланованим та отриманим результатом. Встановлено, що важливо не тільки своєчасно корегувати і моніторити стан та ефективість впроваджених змін, але й передбачати можливі результати внаслідок тривалого функціонування такої системи. Виокремлено тенденції розвитку Болонського процесу в Україні та визначено можливі шляхи підвищення його ефективності. Проаналізовано процес трансформації системи вищої освіти України у зв'язку з впровадженням принципів Болонського процесу. Охарактеризовано сучасний стан, проблеми та ступінь упровадження ключових положень Болонської декларації. Досліджено тенденції розвитку Болонського процесу в Україні. Визначено можливі шляхи підвищення ефективності системи вищої освіти України (на основі досвіду країн-учасниць Болонського процесу). Задля реалізації запланованих завдань проаналізовано законодавчу базу країн-учасниць Болонського процесу. Проведено анкетування 410 студентів із 14 закладів вищої освіти України (галузевих і багатогалузевих) та інтерв'ювання 103 викладачів 3 ВО.

Ключові слова: Болонський процес, кредитно-трансферна система, академічна мобільність, тенденції розвитку, моніторине якості ocsimu. 